\title{
A Perfect Ecosystem for Learning? Modern Thoughts for Organizing Higher Education
}

\author{
Pasi Juvonen*, Anu Kurvinen \\ Business and Culture, Saimaa University of Applied Sciences, 53850, Lappeenranta, Finland
}

\begin{tabular}{l} 
A R T I C L E I N F O \\
\hline Article history: \\
Received: 31 October, 2017 \\
Accepted: 09 January, 2018 \\
Online: 30 January, 2018 \\
\hline
\end{tabular}

Keywords :

experimental development

ecosystem, team

entrepreneurship, team learning

\begin{abstract}
A B S T R A C T
The background of the article lies in South Eastern Finland, in Lappeenranta, where an active University campus has attracted a group of ICT startups as well as SME's in the field to collaboration. The novel education approach also has another remarkable role as a developer and source of innovation. An experimental development ecosystem (EDE), where learning of knowledge, skills and character are combined, is presented in the article. Also future paths of the EDE are discussed. Companies in the ICT field worldwide are in constant need of competent experts who are ready to adopt the new tools and, at the same time, have an entrepreneurial mindset. We argue that inspiring students to learn through appropriate learning methods and providing them with a modern learning environment comes first. ICT tools, applications and systems to support learning objectives come second. The model presented in the article has been studied for some years as action research. The learning methods that have been found beneficial in IT and marketing bachelor education have been spread to other bachelor and master study programs as well. Results from the data show that students who study as team entrepreneurs have learned content knowledge, meta-skills and reflection skills via the learner-centric methods used in EDE. They have also been inspired to employ new ICT tools and applications to support their learning and project work.
\end{abstract}

\section{Introduction}

This article is an extension of the work originally presented in Educon 2017 in Athens in April 2017 [1].

The change in digitalization has been rapid and the change speed has been increasing during the recent decade. Since Facebook, we have seen plenty of new platform business models. Only some of them have succeeded and have been able to capture value for themselves. However, those who have succeeded have been able to capture themselves almost the whole market.

At the same time, many conventional businesses have run into severe challenges caused by rapid digitalization. To give an example, The Finnish Posti - a post delivery company owned by the government - has in recent years laid off employees due the diminishing amount of traditional mail deliveries. At the same time, agile delivery companies have challenged the Finnish Posti by offering customers faster delivery and several add-on services. The Finnish Posti has tried to find new business elsewhere, e.g. from lawn moving services to offering basic health care services.

*Corresponding Author: Pasi Juvonen, Email: pasi.juvonen@saimia.fi
Another example is the Finnish national railway company VR Group, which has held a monopoly for a long time (over 150 years). During the recent years, discussion about free competition in railway traffic has increased, and current plans may be deployed in the 2020s. Already, these plans have caused major reorganizations and layoffs within the VR Group.

There are more such examples found elsewhere in the world, e.g. Eastman/Kodak. When we consider what will happen in higher education, we can foresee what is going to happen in the future. How will platforms such as Khan Academy, Coursera and Udemy, and other more sophisticated platforms developed after them, change the current education systems? How many teachers will be needed in future to teach basic principles of programming, for example, when high-quality content can be freely loaded via learning platforms?

For us as educators and researchers an important question is: Are we going to build a shelter and try to resist the change, or would it be wiser to build a windmill and try to utilize the winds of change as well as possible? 


\section{P. Juvonen et al. / Advances in Science, Technology and Engineering Systems Journal Vol. 3, No. 1, 82-93 (2018)}

In the world of today, there is plenty of information available. Thus, one has to be able to think critically, have skills to synthesize and put the information into action in a wise way. According to Fadel et al. [2], in order to deepen the learning process in the three essential dimensions - knowledge, skills and character qualities an important dimension is needed - meta-learning. This means that there are some internal processes required for our learning, namely reflection and adaptation of our learning. Figure 1 presents the framework for the 21 st century learner and for the curriculum redesign that tries to answer to these needs.

Our practical experiences with the same philosophy started several years ago. We - a group of lecturers - decided to start building a learning environment which would enable utilizing knowledge gained from different sources, combine theory, learning by doing and reflection, and make rapid changes possible when learning needs a change, without rethinking and redesigning the whole curriculum. This learning environment also provides practical measures to show students' progress.

The current curriculum (presented in section 2.1) is a result from coaching altogether 11 student teams comprising altogether more than 150 students from two areas of specialization information technology and marketing. The development of the curriculum took place in 2009 - 2016. Since its early steps in 2009, this learning environment has expanded into a learning ecosystem that we call Experimental Development Ecosystem (EDE). This article describes the ecosystem and its pedagogical background, how the learning is organized within it, and the operational level practices that enable it. In this article, we present and discuss our current state of the art with the EDE, ongoing development activities as well as future development paths.

The article is organized as follows. Chapter 2 presents the results from a literature study about the requirements in bachelor education in Finland and in the OECD context. It also presents the current state of the art with the Experimental Development Ecosystem. Chapter 3 discusses data collection and data analysis. Chapter 4 lists some observations based on the data, and finally, Chapter 5 summarizes the findings and discusses our probable future paths on the subject.

\section{Rapid changes will require rearrangements in organizing learning environments}

Discussion on a right balance between studying explicit content that will, depending on the subject, easily become out-ofdate, and meta-skills that are useful but, at the same time, may leave learners with an experience of not learning anything specific has been going on for a long time. Skills that are easy to teach and learning that is easily measured involve skills that are easily automated [3]. We are, to a certain extent, educating young people for future professions that do not exist when decisions about students' curricula are made. These new professions emerge (and some others disappear) while students are studying for their diploma.

Learning is less about reproducing content knowledge. It is more about extrapolating what we know in novel situations [3]. In future, more employees with versatile skills are needed and, at the same time, fewer specialists with deep expertise in one subject are needed. Communal learning skills and team working in multidisciplinary working groups or teams are important [3].

The demands presented for undergraduate education are versatile. Based on a study of literature [3-10], an undergraduate student needs at least the following skills:

- team working

- communal learning

- problem solving

- creativity and innovativeness

- critical thinking

- decision making

- leadership and self-leadership

- shared expertise

- reflection on one's values, and social and emotional skills.

At the same time, learning environments built for supporting learning should

- offer versatile methods for learning

- diminish teacher-led methods

- provide coaching for the constantly changing world

- foster entrepreneurship

- enable running pilots (e.g. establishing cooperatives).

[3-10].

To get an overall picture of what should be considered when organizing higher education in 2017, we looked for a framework for identifying knowledge, skills, meta-level skills and methods. We also wanted to make a cross-section of the EDE compared to other frameworks. The framework we chose is presented in Figure 1.

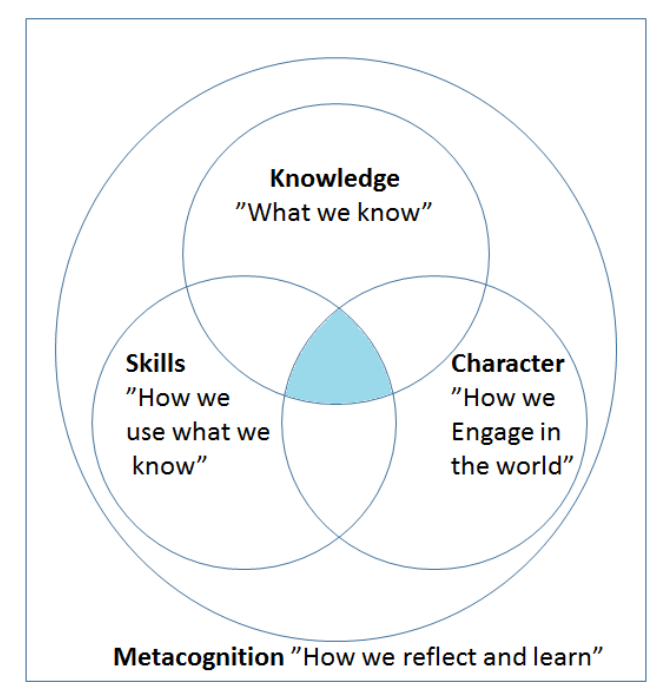

Figure 1. The framework for 21st century education by Centre for Curriculum Redesign [2].

According to [8], there are four forces that lead the learners towards new ways of learning for life in the 21 st century. These forces are:

1. Knowledge work - employees who use brain power as well as digital tools for creating new solutions collaboratively in teams 


\section{P. Juvonen et al. / Advances in Science, Technology and Engineering Systems Journal Vol. 3, No. 1, 82-93 (2018)}

2. Thinking tools - knowledge workers use a set of digital tools, devices and services

3. Digital lifestyles - today's student generations are born into the digital society, and grow up with the digital devices

4. Learning research - the latest research on learning during the last three decades has deepened the understanding of learning processes (See [34 - 37], [39-40], and [51-60] for more)

\subsection{State of the art at our UAS - Experimental Development Ecosystem (EDE)}

Since 2009 we have been developing a new learning environment, combining studying content knowledge (theory), learning by doing (practice), and employing dialogue $[11,12]$ in knowledge sharing, knowledge creation and reflection. Together with several local companies and municipalities, we have been able to build the Experimental Development Ecosystem. The current ecosystem offers our undergraduate students an excellent platform for both studying content knowledge, applying this knowledge in real customer projects, and reflecting what has been learned by doing with other team members and the team coach.

Since 2013 we have been developing the EDE in parallel with several RDI projects supported by the Finnish Funding Agency for Innovation (TEKES), Saimaa UAS and LUT University. An "easy-to-start" cooperation between stakeholder groups with little or no thresholds has been a cornerstone for the further development of the EDE.

The EDE was originally created and developed as a social innovation; it is a novel way to organize bachelor education for IT and Business Administration students specializing in marketing at Saimaa UAS. Tiimiakatemia [13] in Jyväskylä and Proakatemia [14] in Tampere were studied as models of how the core structures of team learning can be established. Both of the above academies are specialized in entrepreneurship. An extensive study of how team learning and team entrepreneurship has been organized at Saimaa UAS with IT students to support entrepreneurship education was carried out by Juvonen in 2014 [15].

In 2014 there was no other learning environment designed to support entrepreneurship education in IT Bachelor education [15]. The current employment of the EDE seems to be the only implementation of team entrepreneurship where a student can specialize in marketing (other deployments focus on entrepreneurship overall) and study as a team entrepreneur combining theory, practice and reflections within the EDE.

Studies on learning environments designed for supporting entrepreneurship education in higher education [16-31], focus on promoting entrepreneurship by fostering either the mindset or skills needed in entrepreneurship, or focus on increasing the status of entrepreneurship as a career choice. Most of the studies we found from Scopus and Science Direct databases (from year 2010 until now) had a narrow focus either on a single course or group of students or a certain technique to foster entrepreneurial skills or thinking. We summarized these studies as follows:

- Applications, tools and methods for fostering entrepreneurial mindset, skills or intentions [19-25]
- Evaluation of entrepreneurship education programs overall [26, 27], perceived of value of entrepreneurship education program [27], evaluation of methods used in entrepreneurship education [28]

- How demand and supply meet on entrepreneurship education [30 - 32]

- Student entrepreneurship [33]

Applications with quite a similar approach than the EDE described in this study were found only at Lund University in Sweden and at University of Southern Denmark [18]. At Lund University, practice-based courses and projects are offered, and best practices are spread within an entrepreneurial ecosystem. At the University of Southern Denmark, there are many entrepreneurship education related courses, where different learning methods are used. Most of them are extra-curricular courses, which complicates student participation. Furthermore, basic concepts are taught in a conservative way and practical issues are learned via intensive courses, or via "real entrepreneurs" as visiting lecturers. An active reflection process has been found effective to unleash creative and innovative thinking potential [18].

Students in these two applications are not studying as team entrepreneurs, so they are not running and developing their own enterprise while they are studying. Rather they are participating in a series of teacher-led courses. Based on these differences, the current deployment of the EDE described in this study is considered as a novel approach to entrepreneurship education.

Also concepts of transformational learning [34] have been applied to service-learning while performing service work in [35]. The EDE is more than a team learning environment (Figure 2).

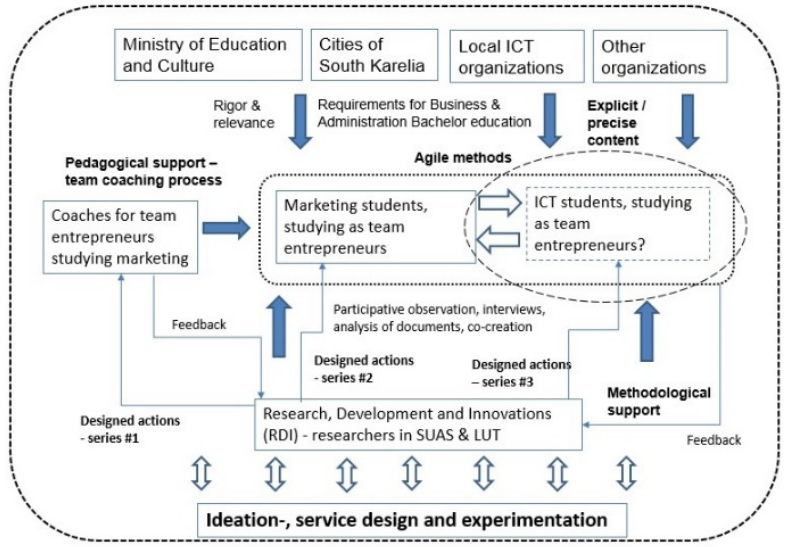

Figure 2. The Experimental Development Ecosystem. Adapted from [36].

The novelty of our approach (the EDE) is in combination of several factors. At the same time this combinations derives the EDE from the approaches found in literature. These factors are as follows:

- Students learn as team entrepreneurs by running a company (a cooperative) they own by themselves

- $\quad$ Focus for students is on specializing in learning marketing in versatile ways

- Experimental learning is emphasized - theory, practice and reflection is involved all the time 


\section{P. Juvonen et al. / Advances in Science, Technology and Engineering Systems Journal Vol. 3, No. 1, 82-93 (2018)}

- A team coaching process where team development, team performance, and team leadership body of knowledge is applied to support learning

- Several stakeholder groups are involved in the implementation of the EDE

- Continuous cooperation between team entrepreneurs, team coaches, and researchers

- The curriculum has been rebuild to support the team learning and team entrepreneurship and it is further developed based on the experiences gained

Currently, Business Administration students who choose to specialize in marketing study their first year in a conventional way, enrolling on conventional study courses. After choosing the specialization in marketing, they continue their studies for two and half years as team entrepreneurs (Figure 3 ).

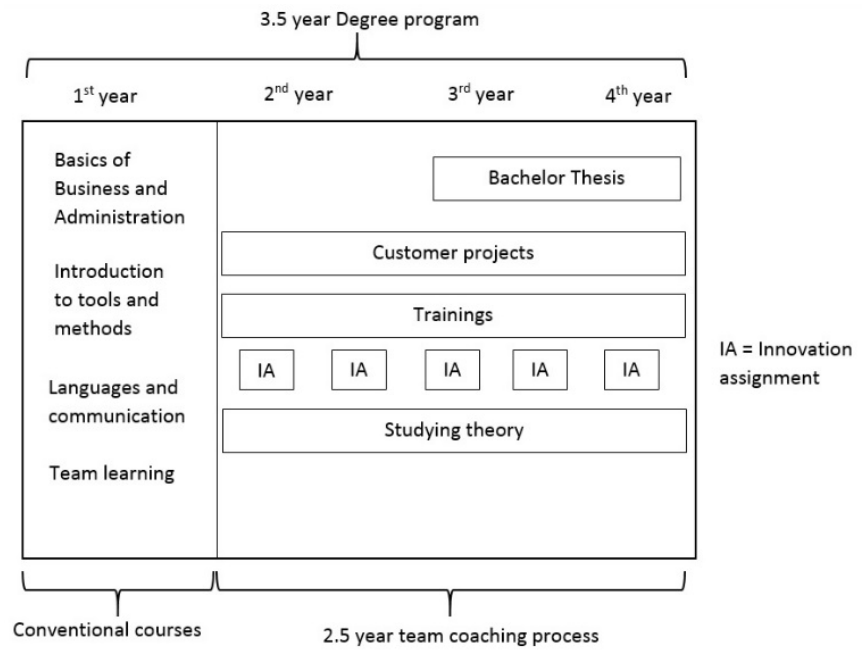

Figure 3. Overview of the curriculum for marketing students studying as team entrepreneurs.

The students who choose to specialize in marketing establish a team enterprise (in the form of a cooperative) and run its operations together during their studies. Their studies consist of studying theory (reading books and articles), carrying out customer projects for real customers for real money, and trainings, where a team coach (personnel of Saimaa UAS) coaches the team members and the team enterprise for team development and performance.

Progress of the team entrepreneurs' studies is measured by five practical measures. Four of these measures show the balance between theory, learning by doing, and sharing knowledge, and reflection. These measures are:

- amount of book points ( 3 book points equal to 1 ECTS point)

- $\quad$ amount of trainings (in hours, 133 hours equal to 5 ECTS points)

- $\quad$ amount of projects (in hours, 80 hours equal to 3 ECTS points)

- amount of innovation assignments (in hours, 80 hours equal to 3 ECTS points).
To give an example, when a team entrepreneur participates in every training session, which take place twice a week, she will get 5 ECTS points for trainings in a half year. Furthermore, when a team entrepreneur works for 16 hours per week in projects, she gets about 6 ECTS points for projects in a half year. Innovation sessions are held at least twice a year, and participating in them increased the ECTS points. The amount of book points is the only individual measure for the team entrepreneurs. Every team entrepreneur has to complete at least 102 book points, which equals 34 ECTS points. This means that every team entrepreneur has to read at least two business books per month. Book trainings are held twice a month, and those who have read a book and returned a book essay before a book training session are allowed to participate.

The measures described above produce the overall results that are monitored at Saimaa UAS, i.e. the numbers of students who complete at least 55 ECTS points per academic year $(1.8-31.7)$. This measure is used by the Finnish Ministry of Education and Culture to monitor study progress in every university of applied sciences in Finland.

The team entrepreneurs are an important element of the ecosystem as collaboration partners and as a scalable source of creativity and innovativeness. Several team entrepreneurs have been recruited already during their studies by local companies. When a company and a team entrepreneur start cooperation on a customer project and continue cooperating on an internship scheme and/or Bachelor's thesis project, it is common, based on our experiences, to continue cooperation after the student has graduated.

The curriculum has been adjusted to make close cooperation with local companies and other organizations possible and fluent. When local companies and other organizations are not able to produce the knowledge they need on their own, they can ask team enterprises for help. A usual method of helping the local organizations is an innovation assignment (IA in Figure 2), where new knowledge is produced within a 12- or 24-hour time limit. Methods of experimental development are used in these assignments in order to create fast, concrete and applicable development ideas based on companies' current needs.

Innovation assignments serve several purposes. For local organizations, they function as a method of rapidly testing their assumptions on a certain topic. For team entrepreneurs, they provide an environment to develop problem-solving skills. Moreover, the assignments function as a measure of team development and substance skills. For all parties, the innovation assignments make it possible to find further cooperation opportunities. In most cases, the organizations participating in an IA will become cooperation partners in the EDE. Sometimes they also take part in RDI projects. Prototypes and/or concepts are usual outcomes of IA's, and prototyping is an important step in an experimental development process. This is the phase that can make a difference in comparison to the traditional workshops where the ideas are easily forgotten after the workshop. It is also easier for the client company to understand the idea and its possibilities for the company after seeing the prototype.

Also research, development, and innovation (RDI) projects support the current EDE model by offering team entrepreneurs 
opportunities to work as research assistants. As research assistants, they learn about research methods, gain an understanding of organizing research processes and ways of producing value for local companies [15]. Acting as research assistants in an RDI project has led to employment via internships and/or Bachelors' thesis projects.

\subsection{Pedagogics used in the Experimental Development Ecosystem (EDE)}

The pedagogics used in the EDE follow ideally the cycle of learning as described by Kolb [37], where learning is described as a process: Firstly, concrete experience is gained, and as the next step in the process, the experience is reflected on. After that comes learning from the experience through abstract conceptualization, and finally testing the newly adopted knowledge and skills through active experimentation.

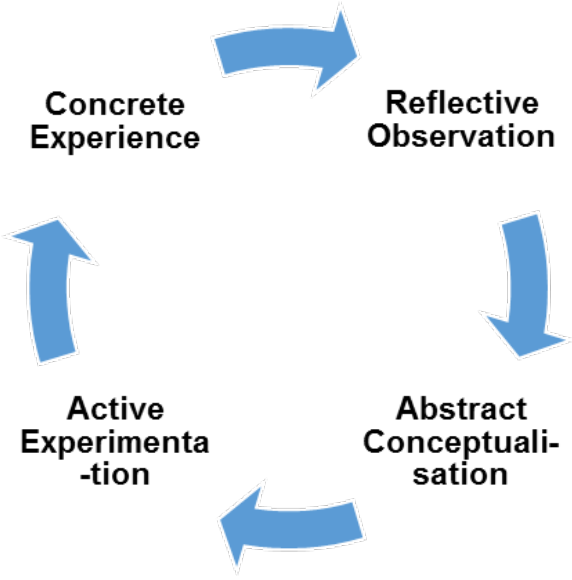

Figure 4. Cycle of learning, adapted from [35].

In constructivism, the learning of a human being is understood as a constant process where individuals are learning or creating their own understanding based on interaction between what they already know and believe, and ideas and knowledge with which they come into contact [38]. Constructivist learning involves at least the following five areas: 1) the educator's attention to the learners, the students and their backgrounds, 2) dialogue facilitation with the group with the purpose of creating a shared understanding of the topic, 3) planned or unplanned introduction of formal theory into the discussion, 4) creating opportunities for the students to challenge or change the existing beliefs and conceptions by using tasks that are structured in a way that makes this possible, and 5) developing students' awareness of their level of understanding and the learning process [39]. In addition to constructivism, team learning, as well as open and honest dialogue, are proven to support the learning objectives.

In the EDE pedagogics, the complexity of companies' operating environments can be learned via concrete experience. At the same time, the theories learned are linked to the reality. Here the principles of building an innovative learning organization are utilized [40]. When considering the current needs of the ICT field, ICT students require more insight into business operations, and practicing business. One way of supporting this is working together in shared projects with team entrepreneur students. Working in multi-disciplinary and heterogeneous project groups is analogous to working life experience, as project teams consist of experts from different fields. Reflection is an elemental part of the learning process and reflective dialogue is used as a pedagogical tool for deepening the learning experience. The researchers working in the ecosystem support the learning process, as they help the students in abstract conceptualization of the phenomena learned. The persons working in the ecosystem need coaching skills that can be applied to the EDE's needs as is required.

These modern thoughts about higher education will also require new skills from those who are employing the system with students. Instead of transferring information to the team entrepreneurs, the emphasis in the team coach's work is rather on helping the process of team development and facilitation of the learning of the information and skills that the team members need for their collaboration and learning (see [41] for more). These teamwork skills and competencies include adaptability, shared situational awareness, performance monitoring and feedback, leadership and team management, interpersonal relations, coordination, communication, and decision making. When these are managed with success, high commitment to learning can be achieved. High commitment usually leads to high performance [42].

A team coach should also make oneself familiar with different styles of consultation. These styles include acceptant, catalytic, confrontational, and prescriptive styles [43]. In the acceptant style, feelings are involved, and this style can be described as emphatic listening. The catalytic style helps the coachee to make decisions. In the confrontational style, the team coach points out what will follow if the coachee continues with her current behavior. The prescriptive style is common in conventional pedagogics. It gives direct advice; however, it does not offer the coachee any opportunity for growth. All these styles are needed in team coaching.

\section{Data collection and analysis}

The research framework for investigating all the development activities concerning the Experimental Development Ecosystem has been action research [44, 45]. During September 2015 September 2017 there were several mini-cycles where designed development activities were carried out in different parts of the EDE, and the team entrepreneurs were active participants in many of these development activities.

The outcome of these development activities was monitored through participative observation. The team coaches are active agents for change when they act with student team entrepreneurs. By choosing to use qualitative methods of inquiry, the authors have, at the same time, committed themselves to continuous reflection of their own values and how they affect the research.

The field notes have provided valuable qualitative data, which has been analyzed with other researchers. Two other team coaches have been involved in the sense-making process of how to utilize 
the current EDE in ICT education and how to foster cooperation between team entrepreneurs specialized in marketing and ICT bachelor students.

Survey and theme-based interviews during a one-year period between 10/2016 - 9/2017, followed by participative observation, have served as the main data collection methods for the study. An overview of the collected data for the study is presented in Table 1.

Table 1: Overview of the data.

\begin{tabular}{|c|c|c|c|}
\hline $\begin{array}{l}\text { Data } \\
\text { collection } \\
\text { method } \\
\end{array}$ & Amount & Timeline & More information \\
\hline $\begin{array}{l}\text { Theme- } \\
\text { based } \\
\text { interviews }\end{array}$ & 12 & $10 / 2016$ & $\begin{array}{l}13 \text { specialists in } 12 \\
\text { interviews, from } \\
\text { different stakeholder } \\
\text { groups involved with } \\
\text { the EDE, were } \\
\text { interviewed to find } \\
\text { out development } \\
\text { targets for the EDE. }\end{array}$ \\
\hline $\begin{array}{l}\text { Participative } \\
\text { observation } \\
\text { sessions }\end{array}$ & Over 50 & $\begin{array}{l}\text { Training } \\
\text { sessions, four } \\
\text { hours twice a } \\
\text { week between } \\
\text { 9/2016 - } \\
\text { 9/2017 }\end{array}$ & $\begin{array}{l}\text { Team coach acts as } \\
\text { an active agent for } \\
\text { development and } \\
\text { provides examples of } \\
\text { digital tools for team } \\
\text { entrepreneurs. }\end{array}$ \\
\hline $\begin{array}{l}\text { Theme- } \\
\text { based } \\
\text { interviews }\end{array}$ & 34 & $\begin{array}{l}/ 2016- \\
9 / 2017, \text { lasted } \\
15-40 \text { minutes }\end{array}$ & $\begin{array}{l}\text { Evaluation of the role } \\
\text { of the ICT / Digital } \\
\text { tools and reflections } \\
\text { on why and how } \\
\text { team entrepreneurs } \\
\text { have been deploying } \\
\text { them. }\end{array}$ \\
\hline Survey & $\begin{array}{l}14 \\
\text { replies }\end{array}$ & $\begin{array}{l}8 / 2017- \\
9 / 2017\end{array}$ & $\begin{array}{l}\text { E-mail survey } \\
\text { followed by } \\
\text { interviews as a part } \\
\text { of development } \\
\text { discussions. }\end{array}$ \\
\hline
\end{tabular}

Methodologically, this article is a partly descriptive and partly explorative case study [46, 47]. It presents the current implementation of the EDE, explores its possible development paths, and finally describes how the ICT Bachelor curriculum could benefit from it.

The basic assumption of the authors is that every research is value-laden and biased. By choosing to use qualitative methods for the inquiry, the authors have, at the same time, committed themselves to continuous reflection on their own values and how they affect the research. In this study, the objective has been the further development of the current EDE and integration of the ICT Bachelor education into it at some level. Therefore, there is an inbuilt bias in the observations and interventions made. However, the authors present the interpretation based on the analysis and the process of conducting research transparently and leave judgement of the validity of study to the reader.

The results of the study have been discussed with three team coaches and two researchers. Luckily, the team coaches share an office at the campus. This has helped to test inner validation of the observations made based on the interviews. The data for the article consists of qualitative interview material (12 specialist interviews with open-ended questions, notes on direct and participative observations, $10+$ steering group meetings, researcher workshops, other workshops and meetings), and several unofficial discussions with colleagues and administrative staff at the Saimaa UAS campus and elsewhere where the authors have been actively involved in development activities.

Multiple sources of data and close cooperation between the two authors made it possible to utilize both investigator triangulation and data triangulation [48]. The triangulation of data and researchers has helped to test inner validation of the observations made based on the interviews and participative observation sessions. The data was analyzed applying the principles of grounded theory $[49,50]$. The grounded theory analysis includes three main phases: open coding, axial coding, and selective coding [49], and the method requires the researcher theoretical sensitivity [51]. The researcher cannot force the data, but instead she has to let the data "speak". Naturally, this phase is extremely hard in cases where interviewers have a lot of pre-existing knowledge about the subject studied. The process can be made easier by asking the same open-ended questions about the subject studied from all the interviewees and carefully listening to and reporting their expressions.

In the open coding phase, interesting phenomena in the data were highlighted. In this study, the interview notes were first gathered into one text file and then analyzed by the two researchers. In the axial coding phase, the interesting phenomena marked in the open coding phase were grouped and their relations (causal and other) were analyzed. In the selective coding phase, a lot of data was abandoned, the core of the results - "What is going on here?" - was taken, and the research reports were written. An example of axial coding phase where i.e. associations and causal relations were searched by visualizing interesting phenomena with Atlas.ti software is presented in figure 5 .

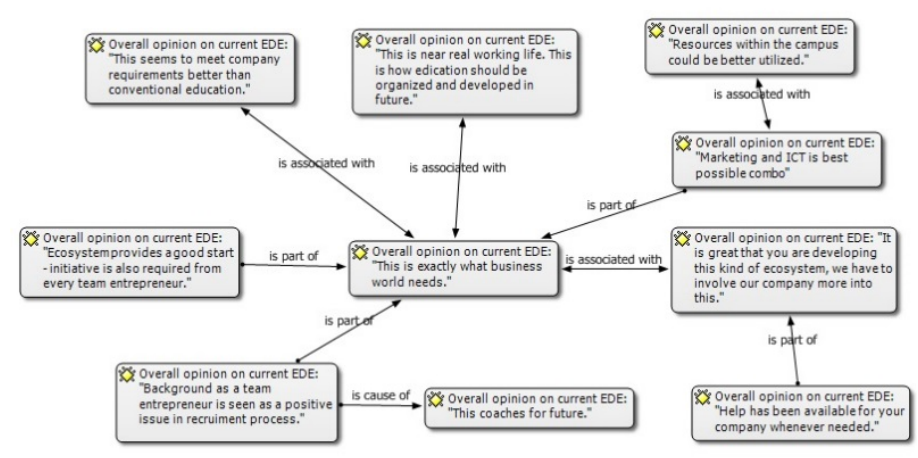

Figure 5. Axial coding with Atlas.ti code network view.

As mentioned above, the grounded theory analysis lets the data speak, and therefore no pre-existing theory is needed. In an ideal case, the grounded theory analysis is purely inductive. In practice, there always exists little or more pre-existing knowledge and bias related to the research subject. To be exact, a target to develop something is already a strong bias. Who defines development? Development for one stakeholder group may be stagnation for another group. When discussing values and biases, the best we can do as researchers is to be as open as possible about the motives we 
recognize in ourselves. In this study, the researchers had a strong vision of how ICT Bachelor education should be organized in future. However, the interviewees were asked open-ended questions about the subject, and the results are presented as they are with no value-laden interpretations added.

Open coding and axial coding phases went on in parallel. During the open coding and axial coding phases, a constant comparative method and theoretical sampling [51, 52] were used. The use of the constant comparative method meant that when an interesting phenomenon was found later during data collection, all the earlier data was screened again to see if the phenomenon was found there, too. Theoretical sampling was used to collect more data on phenomena where more explanation was needed. The data was collected until a theoretical saturation was achieved. The use of the constant comparative method and theoretical sampling increased the researchers' interaction with the data. The selective coding phase also started early and parallel with the axial coding phase. The saturation of the new data [51] took place early, which meant that there was no need for extra interviews on that subject. A new tool for making word clouds was used to visualize part of the data (see Figure 4 for more details).

During the first round of interviews made with stakeholder groups, two seed categories [52] emerged during the open coding phase: 1) creating interdisciplinary interaction during ICT education, and 2) entrepreneurial mindset and its value. Based on an analysis of these seed categories and combined with the analysis of the new field notes (including memos, emails, book essays, and observation data) between January 2016 and mid November 2016, a pattern of "Where should we be heading?" was written. The results were published in a conference article in the Educon 2017 conference in Athens, Greece on $27^{\text {th }}$ April 2017.

At the same time when employing designed actions to the Experimental Development Ecosystem learned from the previous study, two new research questions were chosen for this study:

\section{What are the learning experiences when dialogue is used as learning method? \\ 2. How new ICT tools and applications have been utilized by team entrepreneurs during the first year?}

Between mid of November 2016 and mid November 2017, plentiful new data was gathered and analyzed. This data collection comprised two interview rounds as part of the team entrepreneurs' development discussions, over 50 training sessions (where team entrepreneurs and the team coach were present), and a survey. The survey was presented to the team entrepreneurs face to face and they were able to ask further questions about the purpose of reflecting on these issues. The team entrepreneurs were asked to evaluate their dialogue skills, make observations on dialogue in other groups they had visited, and describe how they had employed ICT tools in their project work. The expressions made by 14 interviewees were later observed in training sessions, project reflection sessions, and finally by end products made with the ICT tools that had been utilized.

\section{Observations based on the data}

In general, the majority of the interviewees within our stakeholder groups shared the opinion that the ecosystem model
(EDE) in modern education is a response to many challenges in the employment of the newly graduated, and at the same time it is a way to pave the way to embarking the working career smoothly after studies. The students' early adoption of an open view of the real business life was generally seen as a positive and novel way of educating experts for the business world, where the described individual capabilities are appreciated by employees.

Entrepreneurial mindset and thinking as a driving force for students was seen as a positive feature to be maintained in education. The necessity of establishing a cooperative and working as team entrepreneurs was seen differently among the interviewees. Some of the interviewees from Saimaa UAS did not see that learning to run an enterprise would bring much value to ICT students. The interviewees from industry, however, saw that learning to think and operate as entrepreneurs would be one of the most important topics to learn overall.

As the most promising pathways, the interviewees saw the possibilities of interdisciplinary interaction between marketing and ICT students, who all are familiarized with the ICT business and the ICT customers' businesses. During the studies, the two student groups could make use of each other's specialty areas by participating in shared projects either in RDI or in business collaboration projects. As the study aims at understanding the future requirements for a competent ICT education, several ICT company representatives were interviewed. As a way to prepare competent future employees for the ICT field, the interviewed ICT companies mentioned a possibility to participate directly in the education of ICT students via both direct education activities and placement opportunities or shared customer projects in RDI, for example. This would create a firm an efficient recruitment process with less need for training the newly recruited personnel.

The interviewees that have graduated from the team entrepreneurship ecosystem or are currently studying marketing in that environment had positive experiences of this type of an education system. The most important and positive feature mentioned was learning through real business cases. The most valuable part in the model was the early networking with businesses. After graduation, it has been easy to find a job relating to the field of studies. At least, this different form of studies in a cooperative has proven a positively differentiating factor in job applications.

ICT business is mostly a project-based business where experience and an entrepreneurial mindset are a benefit as such. The current marketing team entrepreneurs have started to build also cooperation with students from different sectors of education within Saimaa UAS to be able to expand their domain knowledge. Making oneself familiar with different contexts where marketing activities (and ICT) are carried out is another example of a positively differentiating factor for the job applicant.

The ICT education ecosystem and ICT education in general need to respond to the changing skill requirements in the industry. In the EDE this can be promoted by involving the ICT sector in the constant development of the study programme and in the education activities in special projects. This would ideally result in long-term interaction between the ICT industry and the Saimaa University of Applied Sciences (SUAS) and the students. In some cases, even weekly co-operation between the ICT companies and the coach 
and students would form a mutually beneficial cooperation model supporting a high level of motivation among both the students and the ICT companies. When mutual benefits exist and the captured value will be fairly shared between the parties, the cooperation will sustain itself.

There were some concerns towards the coached team learning and team entrepreneurship model raised in the interviews. In general, the team coaches have a key role and they are responsible for ensuring that the students are provided with the basic capabilities required in the education programme at a University of Applied Sciences. It was also stated that this type of a learning method is not ideal for students who still have to grow in order to mature for the responsibility and self-leadership skills that are required by the learning style. The entrance examination for the students was seen as one important step in this process. Also, the new ICT education should be marketed as a more interdisciplinary education program that is not too much technically oriented in order to lure the business oriented people with a high motivation for fast career building.

As the student teams operate in groups or as working teams, it would be beneficial if the different team roles could be consciously tested by each student. This would help the young students safely test their own personal strengths, which would be a supporting factor in building the students' professional self-esteem. As all companies, also the student teams have to set goals for their actions and all the steps during the studies should be taking the team towards the goals. It is not enough to act as active since that does not suffice to develop the situation. Supporting the building of students' versatile knowledge base requires a broad scale of practical learning projects, which has to be ensured during the studies. Here, the role of the team coach is emphasized again. A frequent presentation discussion of the learning goals and how they have (or have not) been achieved is crucial.

In the Business Administration degree program, the number of students who complete 55 ECTS points per year has been monitored since 2014 when criteria for funding University of Applied Sciences was changed. However, the measuring criteria were changed again in 2016, so we do not yet have enough new data to be able to make valid arguments about overall results. In the academic year $2015-2016$, the overall result in achieving 55 ECTS points in the Business Administration and International Business degree programs (measured together) was $57.1 \%$ (68.1 $\%$ with team entrepreneurs). In the academic year 2016-2017, the figures were $61.3 \%$ (58.7\%) respectively. The measuring system is now being updated to be able to provide more accurate data in future.

Even though we do not have enough performance data yet from team entrepreneurs' studying within the EDE, we are able to argue something. One of the biggest worries at the beginning of team learning and team entrepreneurship was how the increased freedom of students in choosing what they study and when will affect the performance measured in ECTS points. With this small amount of data we are able to argue that the pedagogics used with the EDE is working and no one has to worry about the performance metrics.

Two of the interviewees strongly emphasized that in future the EDE should emphasize the role of internationalization of students and companies cooperating in the EDE. This kind of organization of learning, development, and research activities is not familiar elsewhere and therefore the EDE ideas should be exported to other countries as well. The main strengths that this kind of ICT education would offer include the digital thinking of "Digi-native" generations together with marketing capabilities. These make a combination that a successful and competitive international business requires. The students would also, right from the beginning, start to understand that their future work will be part of someone's business - if not their own.

\subsection{Towards a perfect ecosystem of learning}

The key findings, as also described in pedagogic research literature that have proved to be successful in the researched EDE model are the following: authentic learning, mental model building, internal motivation, multiple intelligences as well as social learning. The curriculum applied in Saimaa UAS, as well as the piloted methodology applied on certain study courses, aims at developing skills needed when coping with the complexities of the 21st century: team working skills, communal learning skills, problem solving skills, leadership and self-leadership skills as well as innovativeness, shared expertise, and ability to reflect on one's own values and attitude.

These suggestions follow the advice from studies on how to build great teams. They suggest that energy (how team members contribute to a team as a whole), engagement (how team members communicate with one another), and exploration (how teams communicate with one another) are crucial factors for teams' success [53]. Furthermore, when quality of communication includes balance of advocacy and inquiry, a lot of positive feedback and true interest in others' opinions [54], there are many of the required elements available to develop great teams. Applications selected should support the objectives listed here, and this means they cannot be selected from a teacher-centric viewpoint.

Students' experiences from learning dialogue skills are proving that practicing dialogue in a safe environment gives them valuable communication exercise. It also supports the readiness for dialogue of the future company developers. Within one year's time every respondent said that there is development gained in one's own dialogue skills. Several respondents stated that they already are good at listening to other students. Several stated that they have learned to express their own opinions in the group. Based on external working life experiences, some students also had noticed that in many companies the leadership culture does not encourage dialogue at all. These future employees will be motivated as well as committed when they are part of a team where dialogue exists.

\subsection{Where there's a will there's a way-A practical view of communication technologies and platforms.}

A framework for making interpretations based on the qualitative data analysis for research question 2 had four phases:

1. Notes from interview data (What tools were said to be employed?)

2. Direct and participative observation in training sessions (What tools were actually employed in practice and by who?) 
3. Reflection of what was learned (Who actually participated to implementation of new tools? How tools were selected? Why tools were abandoned?)

4. What outputs were done for customers (Videos, web-sites, etc.) with the ICT tools employed?

These phases helped to validate our findings. When a team entrepreneur expressed in an interview (1) that she was interested to learn a new tool for making videos, later discussed in training session (2) about utilizing the tool in a customer project, reflected the use of same tool when a project was completed (3), and finally the a video was publicly available (4) in social media platform we were able to validate integrity of our chain of making interpretations. An example of how these 14 cases were analyzed is presented in figure 6 .

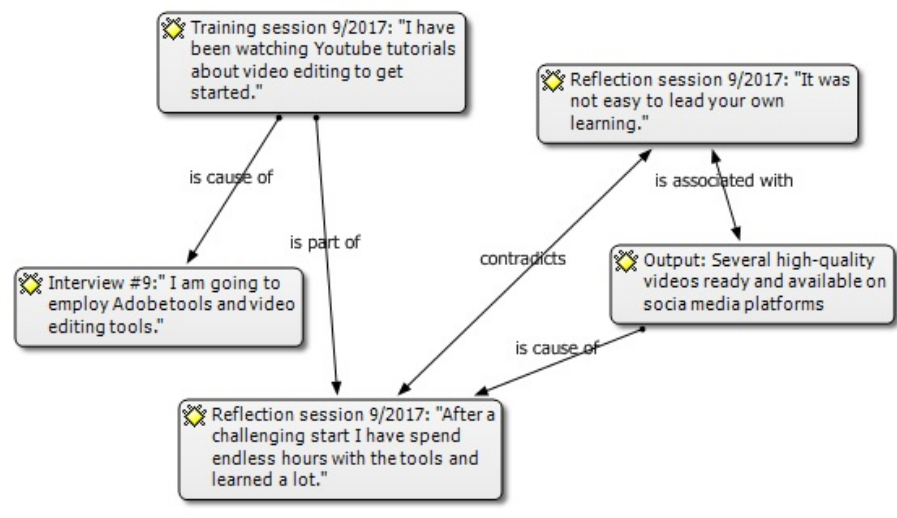

Figure 6. An example of qualitative data analysis, case $\# 9$

Based on our current experience, better utilization of tools and applications is not limited by availability of ICT tools and applications. Rather, it is limited by individual differences in the will to share information about one's working. Sharing workrelated information is a much more sensitive issue than it is usually expected to be. This very same phenomenon limits the use of many other ICT systems as well. Every time when there is competition of projects within teams or departments of the same organization, openness in sharing information is limited. Only part of the employees are willing to share their business contacts via the company-wide CRM system, for example. A better understanding of the benefits of balance between individual work and team work (see [55] for more details) is needed to better utilize ICT systems. Cui bono (Who benefits?) question has to be answered clearly when new systems are employed.

Adopting the use of some practical IT tools while learning in projects is important. To facilitate communications between learners and to support project management, a broad selection of "free to use" tools have been applied within the EDE. The student respondents in the study in August 2017 stated that they had learned to use 4 - 5 new IT tools, applications or platforms on average during one year's time. Some of these tools had been presented by the team coach or a visiting company representative. Currently, also learners find and introduce new tools to the community on a regular basis. The list of the tools, applications and platforms used is long, including the following ones that were mentioned the most frequently: Trello, Slack, Skype, Doodle, WhatsApp, Moodle, Dropbox, Google Drive, Canva, Mention,
Facebook, Twitter, and Instagram. Naturally, email, SMS messages and other conventional communications tools are used as well.

The most frequently used tools in project management were Google Drive, Google Sheets and Trello. In a brief unofficial discussion with the team entrepreneurs from other teams, the same tools were mentioned as the most popular ones in other teams as well.

According to our experiences, it is rather simple for the students to start using new digital tools when working on projects. This also helps students to quickly gain valuable experiences with different tools and platforms and their usability in different tasks. Sometimes students want to challenge themselves by learning to use a new tool, and harness it into the use of their cooperative. There is no need to teach the system itself, but rather act as an example and invite students to use the system. That way they will learn how the real work processes can make use of different technologies.

Though learners are using several tools and applications to support their learning in projects and to facilitate their communication, we are still in the early stages of truly benefitting from digitalization. Technology is not a limitation anymore. The real limitations are found in normal human behavior. To pick an example, a project manager and team members would benefit from knowing what tasks other team members currently have, who might need more tasks do to or who would need help. This data could easily be entered in a Trello table and shared to every team member.

\subsection{Objectives first, systems to support productivity second}

Making experiments and building prototypes [56, 57], associating different types of knowledge [58 - 60], and sharing knowledge of learning experiences [60 - 62] are part of the innovation management concept of the EDE. The team entrepreneurs experiment with different types of tools, applications, systems and platforms to find the ones that are appropriate and useful for their purposes.

Our target with the EDE is to help a new culture of agile methods, applications, and practices to emerge. The easiest way so far has been to start with the team entrepreneurs by introducing new applications to them and just starting using them in project management and communications, when students can directly see the benefit of the systems. So far, the results have been promising.

Experimental development is inbuilt in the EDE, in the form of innovation assignments mentioned before. Also the learning by doing approach, supported by reflection on what was learned, creates confidence in the cooperatives and students' own skills. Dedicating time for reflections is an important learning outcome on the way of becoming a professional in one's own area [63].

\section{Discussion and summary}

Combining and analyzing all data from the stakeholder groups of the EDE and from the team entrepreneurs studying within the ecosystem, we can clearly identify three steps we have to take next: 
1) to leverage lessons learned so far in the ICT bachelor curriculum and master study curricula 2) to re-evaluate how extensively the use of new ICT tools has to be taught, and 3) to set objectives for further studies on the topic.

The current Experimental Development Ecosystem offers a pedagogically solid, tested, experimentally developed, and continuously evolving basis for supporting bachelor education in higher education. Also, the use of digital tools and applications to support learning by doing in projects and to facilitate communications within and between teams has been increasing rapidly.

\subsection{Probable future for the EDE}

Professional development should not focus on educating students about how current professions are executed [64]. As suggested, professional education should rather be focused on developing professions in cooperation between educational institutes and companies. Underneath these suggestions lies the activity theory $[65,66]$. The ultimate goal is to help school and work life to collaborate in a better way. In times of rapid changes, educational arrangements including theory, practice and reflection repeat themselves in a continuing manner.

- International partners are needed to serve both education and business requirements. Companies who are interested in internationalizing their operations will benefit from opportunities for rapid experimentation in two or more locations.

- ICT students need a balanced amount of core ICT skills and business skills. This could be achieved by working with team entrepreneurs studying marketing with the EDE.

- ICT and marketing students should be put in mixed teams for sharing knowledge, and especially for creating new knowledge together. More cross-fertilization is needed for more learning and more versatile ideas.

There is also a lot of work to be done to better integrate the competencies of Saimaa UAS staff into the coaching process of marketing team entrepreneurs and/or ICT students, whether they study as team entrepreneurs or conventional students. This will require a more adaptive attitude towards how learning is organized from all the parties involved: teachers, administration, and team entrepreneurs.

In the beginning, this will require a lot of encouragement because even though higher education teachers may have extensive experience in teaching, they might lack competencies in learner-centric pedagogy and its methods, the mindset required for experimental development, or even both. Changing methods will also require teachers to accept that employing these methods means that they will frequently face situations that are novel to everyone. If someone has a strong routine of teaching, there might not be much interest or will to change it.

When the courage to experiment new methods to support learning is found (usually with support of colleagues or appropriate further education), at the beginning the change of habits will raise anxiety among teachers and learners. Teachers are used to acting as specialists providing answers and at the same time learners have been passive listeners. When tables are turned, both parties feel uncomfortable and the temptation to go back to old habits is strong. If this happens, it will return the potential of learners taking responsibility and teachers role of not giving easy answers to learners directly to zero. During the process of change we have gone through we have seen this phenomenon take place several times.

Very soon teachers, however, usually find out that with longer experience in life in general and operating in different types of situations helps to coach others to find means of how to solve them. Teachers are usually very good at abstracting and conceptualizing what has been learned. By reflecting on the learned skills and discussing how they can be applied in other contexts will help transfer the learning outcomes.

\subsection{How teachers, lecturers and team coaches are able to benefit from the changes}

At the beginning, creating a learning environment required in the 21 st century will take more time than is usually used when organizing courses in higher education. After a two or three years' time, a new culture of students' responsibility for their own learning process will start to emerge and strengthen. At this tipping point, a team coach will recognize that there will be time for tactical and strategic thinking again.

\subsection{Summary}

By combining and analyzing the versatile data we collected, we were able to answer the research questions:

1. What are the learning experiences when dialogue is used as learning method?

\section{How new ICT tools and applications have been utilized by team entrepreneurs during the first year?}

This data shows that dialogue as a learning method was appropriate to support the professional development of the team entrepreneurs. Various new tools for project management, communication, and marketing and sales were employed in practice. It is noteworthy that these ICT tools, applications or systems were not taught. The dialogue and presentation of the tools was enough to inspire action.

The higher education institutes should foster creation of such ecosystems where knowledge, skills and character are combined. The learning environments should provide learner-centric methods, and acknowledge the importance of metacognition. Focusing mainly on content is not enough.

The systems (tools, applications, platforms) needed to support the ecosystem are nowadays mostly free to use and easy to use, meaning that most of them can be applied to practice at a fast pace. These are used in several visionary companies and they should be applied also in higher education institutes if they are not in use yet. The authors warmly welcome new partners to write and discuss the topics covered in this article.

\section{Acknowledgments}

This article has been written as a part of the Digikaappaus project, which is funded by Saimaa University of Applied Sciences, 


\section{P. Juvonen et al. / Advances in Science, Technology and Engineering Systems Journal Vol. 3, No. 1, 82-93 (2018)}

Lappeenranta University of Technology, Tekes - the Finnish Funding Agency for Innovation, and by 11 Finnish organizations.

\section{References}

[1] P. Juvonen, A. Kurvinen, "Developing Experimental Development Ecosystem to serve ICT Education - A follow-up Study of Collaboration possibilites between Stakeholder Groups" in IEEE EDUCON 2017 Conference on 26th April 2017, Athens, Greece. http://ieeexplore.ieee.org/document/7943052/?reload=true

[2] C. Fadel, M. Bialik, B. Trilling, Four-dimensional-education - The competencies learners need to succeed. The Center for Curriculum Redesign, 2015.

[3] OECD, Schooling Redesigned: Towards Innovative Learning Systems, Educational Research and Innovation. OECD Publishing, 2015. http://www.keepeek.com/Digital-Asset-

Management/oecd/education/schooling-redesigned 9789264245914en\#.WYvvnMuwfbg\#page3

[4] S. Leppimäki, T. Meristö, H. Tuohimaa, J. Laitinen, "Future needs for competencies in ICT companies. Tulevaisuuden osaamistarpeet tietotekniikkayrityksissä”, Corporate Foresight Group, CoFi / Åbo Akademi, 2007, (In Finnish).

[5] OECD, "Moving Up the Value Chain: Staying Competitive in the Global Economy", OECD, 2007.

[6] OECD (2012). Education Today 2013: The OECD Perspective, OECD Publishing.

[7] T. Meristö, S. Leppimäki, J. Laitinen, H. Tuohimaa, "The skill foresight of The Finnish Technology Industries. Tulevaisuuden osaamistarpeet teknologiateollisuudessa Yhteenvetoraportti toimialakohtaisista yrityskyselyistä.”, Teknologiateollisuus ry, 2008. (In Finnish).

[8] B. Trilling, C Fadel, 21st Century Skills - Learning for Life in our Times, Jossey-Bass, 2009.

[9] P. Ylä-Anttila, "Dispersion of value chains, future skills requirements change. Sähkö-, elektroniikka- ja tietotekniikka-ala. Tuotantoketjut hajautuvat, osaamistarpeet muuttuvat." ETLA, The Research Institute of the Finnish Economy. 2012, (In Finnish).

[10] R. Rajander-Juusti, "Competency needs in Business and Administration. Liiketalouden osaamistarpeet. Ennakkotietoa koulutuksen suunnittelun tueksi." Raportit ja selvitykset 2013:1. Opetushallitus, 2013, (In Finnish).

[11] D. Bohm, On dialogue, Routledge Classics, 1996.

[12] W. Isaacs, Dialogue: The art of thinking together. Doubleday, Randomhouse Inc, 1999.

[13] Tiimiakatemia. Visited on 11/2017, http:/tiimiakatemia.fi/en

[14] Proakatemia. Visited on 11/2017, http://proakatemia.fi/en/

[15] P. Juvonen, "LEARNING INFORMATION TECHNOLOGY BUSINESS IN A CHANGING INDUSTRY LANDSCAPE. The Case of Introducing Team Entrepreneurship in Renewing Bachelor Education in Information Technology in a University of Applied Sciences.” Doctoral Thesis, Acta Universitatis Lappeenrantaensis 606, 2014.

[16] V. A. Alexandria, P. Parton, A. Robb, "Entrepreneurship Education and Training Programs around the World. Dimensions for Success.", International Bank for Reconstruction and Development / The World Bank, 2014.

[17] R.A. Baron, "Behavioural and Cognitive Factors in Entrepreneurship: Entrepreneurs as the Active Element in New Venture Creation", Strategic Entrepreneurship Journal 1, 167-82, 2007.

[18] C. K. Volkmann, D. B. Audretsch (Eds.) "Entrepreneurship Education at Universities. Learning from Twenty European Cases", Springer International Publishing 2017.

[19] D. La Guardia, M. Gentile, V. Dal Grande, S. Ottaviano, M. Allegra, "A Game based Learning Model for Entrepreneurship Education", Procedia - Social and Behavioral Sciences, 141, 195-199, 2014.

[20] A. Daniel, R. Costa, M. Pita, C. Costa, "Tourism Education: What about entrepreneurial skills?”, Journal of Hospitality and Tourism Management, 30, $65-72,2017$
[21] R.G. Klapper, V.A. Farber, "In Alain Gibb's footsteps: Evaluating alternative approaches to sustainable enterprise education (SEE)", The International Journal of Management Education, 14(3), 422-439, 2016.

[22] R. Bell, "Developing the next generation of entrepreneurs: Giving students the opportunity to gain experience and thrive", The International Journal of Management Education, 13(1), 37-47, 2015

[23] S. Mat, S. Maat, N. Mohd, "Identifying Factors that Affecting the Entrepreneurial Intention among Engineering Technology Students", Procedia - Social and Behavioral Sciences, 211, 1016-1022, 2015.

[24] C. Shlaegel, M Koenig, "Determinants of Entrepreneurial Intent: A MetaAnalytic Test and Integration of Competing Models", Entrepreneurship Theory and Practice, 38(2), 291-332, 2013.

[25] C. Luthje, N. Franke, "The "making" of an entrepreneur: Testing a model of entrepreneurial intent among engineering students at MIT", R\&D Management, 33(2), 135 - 147, 2003.

[26] B. Hj Din, A. Rahim, R. Anuar, M. Usman, "The Effectiveness of the Entrepreneurship Education Program in Upgrading Entrepreneurial Skills among Public University Students", Procedia - Social and Behavioral Sciences, 224, 117-123, 2016.

[27] B, Askun, N. Yıldırım, "Insights on Entrepreneurship Education In Public Universities In Turkey: Creating Entrepreneurs Or Not?", Procedia - Social and Behavioral Sciences, 24, 663-676, 2011.

[28] J. Kirkwood, K. Dwyer, B. Gray, "Students' reflections on the value of an entrepreneurship education", The International Journal of Management Education, 12(3), 307-316, 2014

[29] A.S. Zamberi, A. Bakar, N. Ahmad, "An evaluation of teaching methods of entrepreneurship in hospitality and tourism programs", The International Journal of Management Education, 16(1), 14-25. Forthcoming, 2018.

[30] M. Küttim, M. Kallaste, U. Venesaar, A. Kiis, ”Entrepreneurship Education at University Level and Students' ", Entrepreneurial Intentions, Procedia Social and Behavioral Sciences, 110, 658-668, 2014.

[31] T. Shih, Y-Y. Huang, "A case study on technology entrepreneurship education at a Taiwanese research university." Asia Pacific Management Review, 22(4), 202-211, 2017. https://doi.org/10.1016/j.apmrv.2017.07.009

[32] I, S, Ahmad, M, F. R. Buchanan, "Examining the entrepreneurship curriculum in Malaysian polytechnics." The International Journal of Management Education, 12(3), 397-406, 2014

[33] S , Jansen, T. De Zande, S. Brinkkemper, E. Stam, V. Varma, "How education, stimulation, and incubation encourage student entrepreneurship: Observations from MIT, IIIT, and Utrecht University", The International Journal of Management Education, 13(2) 170-181, 2015.

[34] J. Mezirow, Transformative dimensions of adult learning, Jossey-Bass, 1991.

[35] R. Kiely, "A Transformative Learning Model for Service-Learning: A Longitudinal Case Study", Michigan Journal of Community Service Learning. 12(1), 5-22, 2005.

[36] P. Juvonen, "Comparison of two learning and team entrepreneurship models at a Finnish University of Applied Sciences. Setting the scene for future development", 7(1). International Journal of Engineering Pedagogy, 2017. http://online-journals.org/index.php/i-jep/article/view/6517

[37] D. Kolb, D, Experiental Learning, Prentice-Hall, Englewood Cliffs, NJ, 1984

[38] L. B. Resnick, Introduction. In L. B. Resnick (Ed.), Knowing, learning, and instruction: Essays in honor of Robert Glaser, 1-24, Hillsdale, NJ: Erlbaum, 1989.

[39] V. Richardson, "Constructivist Pedagogy." University of Michigan. Teachers College Record, 105(9) 1623-1640 , 2003. Teachers College, Columbia University, 0161-4681.

[40] R. Sarder, Building an Innovative Learning Organization. A framework to build a smarter workforce, adapt to change and drive growth, Wiley, 2006.

[41] D. Levi, Group Dynamics for teams, 2nd edition, Sage Publications, 2007.

[42] M. Beer, High Commitment High Performance. How to Build a Resilient Organization for Sustained Advantage, Jossey-Bass, 2009.

[43] P. Cockman, B. Evans, B. P. Reynolds, Consulting for Real People. Second Edition. McGraw-Hill Publishing Company, 1999. 
[43] K. Herr, G.L.Anderson, The Action Research Dissertation. A guide for Students and Faculty, Sage Publications, 2005.

[45] E.T. Stringer, Action Research 3rd ed, Sage Publications, 2007.

[46] R.K. Yin, Case Study Research: Design and Methods, Sage, 2003.

[47] K.M. Eisenhardt, M.E. Graebner, Theory building from cases: Opportunities and challenges, Academy of Management Journal, 50(1) 25 - 32, 2007.

[48] N.K. Denzin, Y.S. Lincoln, (eds.), Collecting and Interpreting Qualitative Materials, Sage Publications 2003.

[49] A. Strauss, J. Corbin, Grounded Theory in Practice, Sage Publications, 1997.

[50] U. Flick, An Introduction to Qualitative Research. 4th ed. Sage Publications, 2009.

[51] B.G. Glaser, Theoretical sensitivity. Advances in the Methodology of Grounded Theory. Sociology Press, 1978.

[52] B.G. Glaser, Emergence vs. Forcing: basics of grounded theory analysis. Sociology Press, 1992.

[53] A. Pentland, The New Science of Building Great Teams. Harvard Business Review, April 2012.

[54] M. Losada, E. Heaphy, The Role of Positivity and Connectivity in the Performance of Business Teams. American Behavioral Scientist, 47(6), 740 $765,2004$.

[55] P. Lencioni, The five dysfunctions of a Team. A workshop for teams, JosseyBass, 2012.

[56] M. Schrage, Serious Play. How the World's Best Companies Simulate to Innovate, Harvard Business School Press, 2000.

[57] N. Furr, Dyer, J, The Innovator's Method. Bringing the Lean Startup into your Organization, Harvard Business Review Press, 2014.

[58] J. Dyer, H. Gregersen, C.L. Christensen, The Innovator's DNA. Mastering the Five Skills of Disruptive Innovators. Harvard Business Review Press, 2011.

[59] E. Wenger, R. McDermott, W.M. Snyder, Cultivating Communities of Practice. A guide to managing knowledge, Harvard Business School Press 2002.

[60] J.R. Katzenbach, D.K. Smith, The Discipline of Teams. A MindbookWorkbook for Delivering Small Group Performance, John Wiley \& Sons, 2001.

[61] G. Von Krogh, K. Ichijo, I. Nonaka, Enabling Knowledge Creation. How to Unlock the Mystery of Tacit Knowledge and Release the Power of Innovation, Oxford University Press, 2000.

[62] P.J. Denning, R. Dunham, The Innovators Way. Essential practices for successful Innovation, The MIT Press, 2010.

[63] D. Boyd, R. Keogh, D. Walker, Reflection: Turning Experience into Learning, Kogan Page, 1985.

[64] J. Virkkunen, H. Ahonen, M. Schaupp, L. Lintula, Toimintakonseptin yhteisen kehittämisen mahdollisuus. TYKES, raportteja 70, 2010, (In Finnish).

[65] L.S. Vygotsky, Mind in Society: The Development of Higher Psychological Processes. Harvard University Press, 1978.

[66] Y. Engeström, Developmental work research: Expanding activity theory in practice, Lehmanns Media, 2005. 